\title{
The Role of Fibroblast Growth Factor Receptor 3 (FGFR3) and Androgen Receptor (AR) in a Non-invasive Urothelial Carcinoma Recurrences
}

\author{
Oki Meilani Dewi, Sri Suryanti, Bethy Suryawathy Hernowo \\ Department of Anatomical Pathology, Faculty of Medicine, Universitas Padjadjaran/ \\ Dr. Hasan Sadikin General Hospital, Bandung, Indonesia
}

\begin{abstract}
Urothelial carcinoma is a bladder carcinoma that took place in the urinary tract. Non-invasive urothelial carcinoma patients have high recurrence rates $(50-70 \%)$. The recurrences took so many years that may lead to the high-cost treatment and low survival rate. Fibroblast growth factor receptor 3 (FGFR3) and androgen receptor (AR) known to play a role in non-invasive urothelial carcinoma and potentially act as a prognostic marker to predict recurrences. This study aimed to discover the role of FGFR 3 and AR in recurrences of non-invasive urothelial carcinoma. This research used a case-control study design. Samples took from patients diagnosed with non-invasive urothelial carcinoma registered at Dr. Hasan Sadikin General Hospital Bandung 1 January 2010-30 December 2015 period. Sixty samples consisted of 30 recurrent groups, and 30 non-recurrent groups individually fixated and embedded to paraffin block for FGFR3 and AR immunohistochemistry analysis. Analysis chi-square performed with a level of confidence $95 \%$ and statistical power $95 \%$. p values $<0.05$ were considered to be statistically significant. Statistical analysis showed that FGFR3 immunoexpression was found significantly low on the recurrence group ( $\mathrm{p}=0.002$, $\mathrm{OR}=5.50)$. While AR immunoexpression was found insignificant $(\mathrm{p}=1.000, \mathrm{OR}=1.00)$. FGFR3 immunoexpression from samples in the recurrent group with multiple tumors found to be significantly low $(\mathrm{p}=0.031, \mathrm{OR}=6.067)$. This study showed that recurrences took place when FGFR3 lowly expressed within non-invasive urothelial carcinoma samples with multiple tumors. This finding may raise a candidate to early-predict the recurrence, thus will suggest early therapy.
\end{abstract}

Key words: AR, FGFR3, non-invasive urothelial carcinoma, recurrence

\section{Peranan Fibroblast Growth Factor Receptor 3 (FGFR3) dan Reseptor Androgen (RA) terhadap Kejadian Rekurensi pada Karsinoma Urotelial Buli Non-invasif}

\begin{abstract}
Abstrak
Karsinoma urotelial merupakan karsinoma buli yang sering terjadi pada saluran kemih. Karsinoma urotelial dibagi menjadi karsinoma urotelial non-invasif dan invasif. Pasien karsinoma urotelial non-invasif mempunyai kejadian rekurensi tinggi (50-70\%) dan membutuhkan waktu lama untuk memantau kejadian rekurensi sehingga membutuhkan biaya tinggi dengan angka ketahanan hidup rendah. Fibroblast growth factor receptor 3 (FGFR3) dan reseptor androgen (RA) berperan dalam terjadinya karsinoma urotelial non-invasif dan berpotensi sebagai penanda prognostik yang memprediksi rekurensi secara akurat. Tujuan penelitian ini mengetahui peranan FGFR3 dan RA terhadap kejadian rekurensi pada karsinoma urotelial non-invasif. Penelitian menggunakan rancangan case-control study. Sampel berupa blok parafin yang diagnosis sebagai karsinoma urotelial non-invasif di RSUP Dr. Hasan Sadikin Bandung periode 1 Januari 2010-30 Desember 2015. Sebanyak 6o sampel dievaluasi terdiri atas 30 sampel kelompok rekurensi dan 30 kelompok tidak rekurensi. Pemeriksaan imunohistokimia menggunakan antibodi FGFR3 dan RA. Analisis menggunakan uji chi-square dengan taraf kepercayaan 95\% dan kuasa uji (power test) 95\%. Nilai $\mathrm{p}<0,05$ dianggap signifikan secara statistik. Pada analisis statistik, imunoekspresi FGFR3 rendah signifikan pada kelompok rekurensi $(\mathrm{p}=0,002 ; \mathrm{OR}=5,50)$ dan imunoekspresi RA tidak signifikan $(\mathrm{p}=1,000$; $\mathrm{OR}=1,00)$. Imunoekspresi FGFR3 rendah dengan tumor multipel signifikan pada kelompok rekurensi $(\mathrm{p}=\mathrm{O}, \mathrm{O} 31$; $\mathrm{OR}=6,067)$. Hasil penelitian menunjukkan bahwa rekurensi terjadi ketika FGFR3 terekspresi rendah pada sampel karsinoma non-invasif dengan tumor multipel. Hal ini dapat menjadi penanda memprediksi kejadian rekurensi sehingga dapat dilakukan terapi yang lebih cepat.
\end{abstract}

Kata kunci: FGFR3, karsinoma urotelial non-invasif, RA, rekurensi

Received: 15 August 2018; Revised: 12 August 2019; Accepted: 12 August 2019; Published: 31 August 2019

Correspondence: Oki Meilani Dewi, dr. Department of Anatomical Pathology, Faculty of Medicine, Universitas Padjadjaran/ Dr. Hasan Sadikin General Hospital. Jln. Pasteur No. 38, Bandung 40161, West Java, Indonesia. Phone: (+6222) 2034953. Mobile: 081321709953. E-mail: okimeilani.dr@gmail.com 


\section{Introduction}

Bladder carcinoma is the most common malignancy occurring in the urinary tract, and 3 to 4 times more likely to develop in men than women. Bladder carcinoma takes place in the urinary tract, which originated from bladder transitional epithelial cell. ${ }^{1-3}$ In Indonesia, bladder carcinoma is the seventh most common carcinoma with an occurrence rate of 5.8 in every 100,000 people/year and mortality rate of 3.1 in every 100,000 people/year. ${ }^{4}$ According to Dr. Hasan Sadikin General Hospital Bandung medical record, urothelial bladder carcinoma was ranked the fourteenth most common malignancy with 86 cases recorded in 2016.

Urothelial carcinoma is the most often type of bladder carcinoma with occurrence rates 8090\% of all bladder carcinoma cases. ${ }^{1,2,5}$ Clinically, urothelial carcinoma classified into two groups based on muscle invasion degree, which are noninvasive and invasive urothelial carcinoma. The most commonly diagnosed carcinoma is the noninvasive or superficial urothelial carcinoma or non-muscle invasive bladder cancer (NMIBC), around $70-80 \%$ of patients. Non-invasive bladder urothelial carcinoma also classified into a low and high degree of non-invasive papillary urothelial carcinoma (pTa); in situ urothelial carcinoma (pTis); and infiltrating urothelial carcinoma which has invade lamina propria (pT1)., ${ }^{2,3,6-11}$

The therapy for non-invasive bladder urothelial carcinoma is transurethral resection of the bladder tumor (TURBT) followed by intravesical chemotherapy or immunotherapy. Although patients have undergone therapy, the recurrence rate is still around $50-70 \%$ in a year and could reach $31-78 \%$ in 5 years. In $15-25 \%$ non-invasive urothelial carcinoma cases can progressively evolve to an invasive urothelial carcinoma. $^{10}$

Recurrences defined as relapse carcinoma post-initial resection and histopathologically confirmed. ${ }^{12}$ Clinically, predictive factors that may cause recurrences are the tumor amount, tumor size, prior recurrence state, in situ coexistent carcinoma, pathological stages, and degree of histopathological. These predictive factors are utilized to stipulate the recurrences through a scoring system and risk table calculation, performed on first and fifth-year post-therapy. Hence a molecular marker is required to anticipate recurrences on non-invasive bladder urothelial carcinoma. ${ }^{10,13}$
Genetic evidence shows that urothelial carcinoma can develop from two molecular pathways: FGFR3, which play a significant role in non-invasive bladder urothelial carcinoma; and TP53. FGFR itself is a high-affinity tyrosine kinase transmembrane receptor that is important for embryogenesis, cell growth, differentiation, proliferation, and angiogenesis. FGFR has 4 active isoforms, which are FGFR1, FGFR2, FGFR3, and FGFR4. FGFR3 signaling pathway particularly can activate the androgen receptor (AR) activity. ${ }^{1,11,14-16}$

Androgen receptor (AR) is an intracellular steroid hormone receptor found in cytoplasm or nucleus. It has a role in causing urothelial bladder carcinoma through the genomic and non-genomic pathway, for example, through FGFR3 pathway. ${ }^{15}$ Androgen receptor found majorly expressed on urothelial carcinoma cases (44-78\% of cases) while it is not expressed in benign urothelium tumor. 3,17

In recent years, several studies have been carried out on FGFR3 and AR in urothelial bladder carcinoma, and the results reported are varied and controversial. A study of van Rhijn et al. ${ }^{18}$ reported that the FGFR3 mutation was a predictive of recurrence in low and high degree urothelial carcinoma. Nam et al. ${ }^{12}$ reported that in univariable analyzes AR expression was lower in recurrence. In multivariate analysis, there is a significant relationship between AR expression with low recurrence.

The objective of this study is to understand the role of FGFR3 and AR in recurrent non-invasive urothelial carcinoma, thus can early-anticipate the recurrence possibility and help to conduct proper treatment.

\section{Methods}

Samples were taken from TURBT surgery patients biopsy tissue. Patients registered at Dr. Hasan Sadikin General Hospital Bandung, and histopathologically diagnosed with noninvasive urothelial carcinoma period 1 January 2010-30 December 2015. Sixty samples were acquired, which then divided into two groups: the recurrent group $(n=30)$ and non-recurrent group $(n=30)$. Tissue samples were then fixated and embedded to paraffin block for FGFR3 and AR immunohistochemistry staining procedure in each group.

Mouse monoclonal antibody FGFR3 (Santa Cruz, B-9, SC-13121, USA) with 1:100 dilution, 
and human AR monoclonal antibody (Santa Cruz, 441, SC-7305, USA) with 1:50 dilution used in standard immunohistochemistry (IHC) staining procedure. FGFR3 immunoexpression rated and scored by calculating the number of cells showed immunoreactivity, which was the cytoplasm-stained cells. AR immunoexpression was the nucleus-stained cells. Distribution score was explained as $\mathrm{O}=$ negative; $1 \leq 10 \% ; 2=10-50 \%$; $3=50-80 \%$; and $4 \geq 80 \%$. Intensity score was explained as $0=$ negative; $1=$ weak; $2=$ medium; $3=$ strong.19 Histoscore (distribution $\mathrm{x}$ intensity) was interpreted as $\geq 6=$ high; and $<6=$ low. IHC staining result was examined by two experts in the IHC technique using light microscope Olympus CX31.

Data obtained from this research analyzed with chi-square test for a significant difference. A significant difference interpreted from $\mathrm{p}$-value with $\mathrm{p} \leq 0.05$ statistical significant difference, while $\mathrm{p} \geq 0.05$ showed otherwise. Odds ratio (OR) used to measure the association between exposure and outcome. In this research, it was the association between FRGR3 and AR immunoexpression; and non-invasive bladder urothelial carcinoma recurrences. The data attained from laboratory procedure recorded in distinct form and SPSS 24.0 for Windows used to analyze the data.

Samples attained after approval by the Health Research Ethics Committee, Faculty of Medicine, Universitas Padjadjaran Bandung with assessment letter number: 73/UN6.KEP/ $\mathrm{EC} / 2018$.

\section{Results}

Characteristics of research subjects used based on epidemiology are age, sex, and smoking risk factors. Based on recurrence prediction factors used by the European Association of Urology (EAU) consisting of tumor size, the number of tumors, pathological stage, and histopathological degree. The results of the comparative analysis of the characteristics of the recurrence and nonrecurrence groups showed no differences in the characteristics of the two groups at the beginning of the study.

The results of the FGFR3 immunoexpression

Table 1 Comparison between Research Participant Characteristic on Recurrent and Non-recurrent Group

\begin{tabular}{|c|c|c|c|}
\hline \multirow[b]{2}{*}{ Variables } & \multicolumn{2}{|c|}{ Groups } & \multirow[b]{2}{*}{ p Value } \\
\hline & $\begin{array}{c}\text { Recurrent } \\
(n=30)\end{array}$ & $\begin{array}{c}\text { Non-recurrent } \\
(n=30)\end{array}$ & \\
\hline $\begin{array}{l}\text { Age (years) } \\
\quad \text { Mean } \pm \text { Std }\end{array}$ & $59.56 \pm 12.133$ & $60.00 \pm 12.982$ & 0.894 \\
\hline $\begin{array}{l}\text { Sex } \\
\quad \text { Male } \\
\text { Female }\end{array}$ & $\begin{array}{r}24 \\
6\end{array}$ & $\begin{array}{r}28 \\
2\end{array}$ & 0.254 \\
\hline $\begin{array}{l}\text { Smoking risk } \\
\text { Yes } \\
\text { No }\end{array}$ & $\begin{array}{r}22 \\
8\end{array}$ & $\begin{array}{r}25 \\
5\end{array}$ & 0.347 \\
\hline $\begin{array}{l}\text { Tumor size } \\
\quad \geq 3 \mathrm{~cm} \\
<3 \mathrm{~cm}\end{array}$ & $\begin{array}{l}18 \\
12\end{array}$ & $\begin{array}{l}12 \\
18\end{array}$ & 0.121 \\
\hline $\begin{array}{l}\text { Number of } \mathrm{t} \\
\text { Single } \\
\text { Multiple }\end{array}$ & $\begin{array}{l}12 \\
18\end{array}$ & $\begin{array}{l}20 \\
10\end{array}$ & 0.038 \\
\hline $\begin{array}{l}\text { Pathological } \\
\text { pTa } \\
\text { pT1 } \\
\text { pTis }\end{array}$ & $\begin{array}{r}5 \\
24 \\
1\end{array}$ & $\begin{array}{r}9 \\
21 \\
0\end{array}$ & 0.952 \\
\hline $\begin{array}{l}\text { Histological } \\
\text { Low } \\
\text { High }\end{array}$ & $\begin{array}{r}6 \\
24\end{array}$ & $\begin{array}{l}11 \\
19\end{array}$ & 0.152 \\
\hline
\end{tabular}


Table 2 FGFR3 Immunoexpression Histoscore Comparison between Recurrent and Nonrecurrent Group

\begin{tabular}{lcccc}
\hline \multirow{2}{*}{$\begin{array}{l}\text { FGFR3 } \\
\text { Immuoexpression }\end{array}$} & \multicolumn{2}{c}{ Groups } & OR CI (95\%) & p Value \\
\cline { 2 - 4 } & $\begin{array}{c}\text { Recurrent } \\
(\mathbf{n}=\mathbf{3 0})\end{array}$ & $\begin{array}{c}\text { Non-recurrent } \\
(\mathbf{n}=\mathbf{3 0})\end{array}$ & & \\
\hline High & 10 & 22 & $5.50(1.813-16.681)$ & 0.002 \\
Low & 20 & 8 & & \\
\hline
\end{tabular}

Table 3 AR Immmunoexpression Histoscore Comparison between Recurrent and Nonrecurrent Group

\begin{tabular}{lcccc}
\hline AR Immuoexpression & \multicolumn{2}{c}{ Groups } & OR CI (95\%) & p Value \\
\cline { 2 - 4 } & $\begin{array}{c}\text { Recurrent } \\
(\mathbf{n = 3 0 )}\end{array}$ & $\begin{array}{c}\text { Non-recurrent } \\
(\mathbf{n = 3 0})\end{array}$ & & \\
\hline High & 3 & 3 & $1.0(0.185-5.403)$ & 1.000 \\
Low & 27 & 27 & & \\
\hline
\end{tabular}

Table 4 Comparison between FGFR3 and AR Immunoexpression Histocores on Patients with Single Tumor on Recurrent and Non-recurrent Group

\begin{tabular}{lcccc}
\hline Variables & \multicolumn{2}{c}{ Groups } & OR CI (95\%) & p Value \\
\cline { 2 - 3 } & $\begin{array}{c}\text { Recurrent } \\
(\mathbf{n = 1 2})\end{array}$ & $\begin{array}{c}\text { Non-recurrent } \\
(\mathbf{n = 2 0})\end{array}$ & & \\
\hline FGFR3 immunoexpression & 5 & 15 & $0.238(0.052-1.100)$ & 0.059 \\
$\quad$ High & 7 & 5 & & \\
$\quad$ Low & 0 & 1 & 0.000 & 1.000 \\
AR immunoexpression & 12 & 19 & & \\
$\quad$ High & & &
\end{tabular}

Table 5 Comparison between FGFR3 and AR Immunoexpression Histoscores on Patients with Multiple Tumor on Recurrent and Non-recurrent Group

\begin{tabular}{lcccc}
\hline \multirow{2}{*}{ Variables } & \multicolumn{2}{c}{ Groups } & OR CI (95\%) & p Value \\
\cline { 2 - 3 } & $\begin{array}{c}\text { Recurrent } \\
(\mathbf{n = 1 8})\end{array}$ & $\begin{array}{c}\text { Non-recurrent } \\
(\mathbf{n = 1 0})\end{array}$ & & \\
\hline FGFR3 immunoexpression & & 3 & $6.067(1.107-33.238)$ & 0.031 \\
$\quad$ Low & 13 & 7 & & \\
$\quad$ High & 5 & 2 & $0.800(0.110-5.819)$ & 1.000 \\
AR immunoexpression & 3 & 8 & & \\
$\quad$ High & 15 & & & \\
$\quad$ Low & & & & \\
\hline
\end{tabular}

histoscore category showed $\mathrm{p}$ value $<0.05$ $(\mathrm{p}=0.002)$, while the AR immunoexpression histoscore category obtained p>0.05
( $p=1.000$ ). The results between FGFR3 and AR immunoexpression histoscore on patients with single tumors characteristic on recurrent 


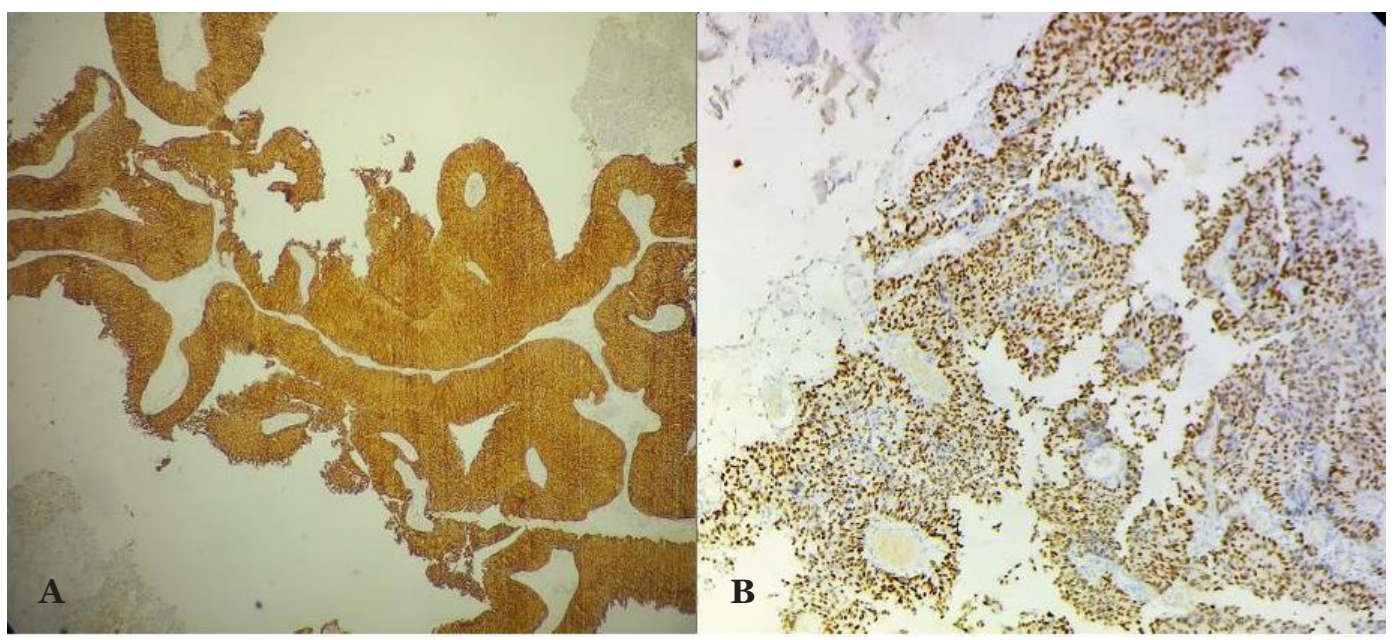

Figure (A) Immunoexpression FGFR3 and (B) Immunoexpression AR with Strong Intensity. Original Magnification, $\times 400$

and non-recurrent groups obtained $\mathrm{p}>0.05$ ( $\mathrm{p}=0.059$ for FGFR3 and $\mathrm{p}=1.000$ for $\mathrm{AR}$ ), which means not significant, whereas FGFR3 immunoexpression histoscore with multiple tumor characteristic obtained $\mathrm{p}$ values<0.05 $(p=0.031)$ which means statistically significant, while AR immunoexpression histoscore with multiple tumor characteristic obtained $\mathrm{p}>0.05$ $(\mathrm{p}=1.000)$ which means it is not significant.

Statistical analysis result on research groups showed that both groups were homogenous, which means both groups were feasible to be compared and perform a further statistical hypothesis test, the only number of tumor that will alter the result between both groups (Table 1).

Statistical analysis showed that there was a significant difference in FGFR3 immunoexpression proportion between the recurrent and non-recurrent group. Odds ratio value from the test showed that patients with low FGFR3 immunoexpression are 5.5 times more likely to suffer from recurrence compared to patients with high FGFR3 immunoexpression (Table 2).

Statistical analysis showed that there was no significant difference in AR immunoexpression proportion between the recurrent and nonrecurrent group. Odds ratio value from the table above showed that patients with low AR immunoexpression are one time more likely to suffer from recurrence compared to patients with high AR immunoexpression (Table 3).

Statistical analysis showed that there was no statistically significant difference between FGFR3 and AR immunoexpression proportion; and single tumor characteristic on the recurrent and non-recurrent group (Table 4).

The result showed that there was a statistically significant difference in proportion between patients with low FGFR3 immunoexpression and multiple tumor characteristic on the recurrent and non-recurrent group. From the odds ratio, patients with low FGFR3 immunoexpression on multiple tumors are 6.067 times more likely to suffer from recurrence compared to patients with high FGFR3 immunoexpression. AR immunoexpression variable found to have no statistical (Table 5).

\section{Discussion}

Urothelial carcinoma is the most common bladder malignancy, with around 90\% of all cases. Most bladder carcinoma incidence occurs in men in the age above 50, with smoking as the primary risk factor. ${ }^{20}$ The finding goes parallel with this research, where $86.7 \%$ of patients are male around the age of $59.78 \pm 12.460$, and $78.3 \%$ were smoking.

Non-invasive bladder urothelial carcinoma has a high recurrence rate, which is $50-60 \%$, and likely to develop into progressive (state of) carcinoma around $15-25 \%$ in 5 years. Urothelial carcinoma originated from urothelium cancer stem cell which distributed to urothelium through migration. It behaves like a multifocal tumor, and result in recurrences. There are four reasons why 
recurrences take place in urothelial carcinoma. They are incomplete resection on primary urothelial carcinoma; tumor cell reimplantation; unknown tumor cells when the primary tumor resection occur; and a new tumor formation..$^{21,22}$

In this study, we found that patients in the recurrent group have statistically significant low FGFR3 immunoexpression $(\mathrm{p}=0.002)$ with OR 5.50 and CI (1.813-16.681). FGFR3 might play a significant role in non-invasive bladder urothelial carcinoma recurrence. In summary, the possibility of recurrences took place in noninvasive bladder carcinoma patients with low FGFR3 immunoexpression is 5.5 times compared to patients with high FGFR3 immunoexpression.

Results attained in this research are in line with the research conducted by van Rhijn et al., ${ }^{18}$ which stated that low FGFR3 expression is a strong indicator in non-invasive bladder carcinoma recurrences. The assumed recurrences caused by the remaining cancer stem cells that were still intact on the primary tumor site after primary tumor resection. On the low FGFR3 immunoexpressed tumor, cancer stem cells suspected of undergoing a slower proliferation rate. They also act as weak cell-cell interaction and poor stromal strength, altogether causing tumor cells to reimplant in the bladder epithelium easily. They migrated to inside the epithelium as well as leading to trouble-free stromal invasion. Patients with low FGFG3 immunoexpression are likely to experience recurrences in numerous sites and multiple growths.

On AR IHC staining analysis, p-value attained was 1.000 with OR 1.0 and CI (0.185-5.403), which showed that no significant difference in the proportion of AR expression between the recurrent and non-recurrent group. These results similar to results by Miyamoto et al. ${ }^{19}$ and Mir et al., ${ }^{24}$ which discovered that $12.9 \%$ of samples (61 cases out of 472) were positive AR immunoexpression. Only $9.0 \%$ detected on noninvasive bladder carcinoma, and $\mathbf{1 5 . 1 \%}$ detected on invasive bladder carcinoma. There was no difference in (AR) expression between male and female patients, and no statistically significant difference in urothelial carcinoma recurrences. There are some dissimilarities between the result from this research and other research, due to the variation in IHC expression and biological function. IHC method has a threshold in approaching (detecting) cells that express the corresponding protein. Thus there might be a chance that the IHC technique reveals falsenegative results because the samples express the insufficient amount of AR to be detected, which the AR did express. ${ }^{6,19,24,25}$

Based on the bivariate analysis test, FGFR3 and AR simultaneously do not affect recurrence events, and only FGFR3 is related to recurrence events. It suggested that the role of AR in bladder urothelial carcinoma through non-genomic pathways with activation of FGFR3 does not occur due to low FGFR3 immunoexpression. Inactive AR causes inactivate gene transcription in the cell nucleus, which further proliferates urothelium cells. The process causes epithelial cell hyperplasia to atypia, then to dysplasia and finally to urothelial carcinoma occurrence.

According to Table 1 , there was a statistically significant difference in the number/amount of tumor characteristic between the recurrent and non-recurrent group. For that reason, the chi-square test performed on FGFR3 immunoexpression category. Fisher Exact test used to analyze the AR immunoexpression category. We can compare the FGFR3 and AR immunoexpression histoscore on patients with single and multiple tumors characteristic on the recurrent and non-recurrent group. In our study, we found that there was no statistically significant difference in the proportion of FGFR3 and $\mathrm{AR}$ immunoexpression variable on patients with single tumor characteristic on the recurrent and non-recurrent group with $\mathrm{p}$ value $>0.05$.

Comparison between FGFR3 and AR immunoexpression histoscore on multiple tumor characteristic patients, on the recurrent and non-recurrent group, revealed that there was a statistically significant difference in proportion between the FGFR3 immunoexpression variable and multiple tumor characteristic on the recurrent and non-recurrent group $(\mathrm{p}=0.031)$ with $\mathrm{OR}$ 6.607 and CI (1.107-33.238). The opposite result obtained from AR immunoexpression variable, where there was no statistically significant difference with a p value $>0.05$.

Multiple tumors have an unstable genetic characteristic, and the loss of cell adhesion will cause the intraepithelial migration of tumor cells. There were two theories proposed to explain the multifocality in urothelial carcinoma. The first theory, the monoclonal theory, which elaborates that multiple tumors rise from one progenitor cell that undergoes sort of changes. They proliferate and spread to the whole urothelium through 
intraluminal implantation or intraepithelial migration. Tumor cells extravasation from the primary site followed by tumor cell implantation in the different urothelium area leading to intraluminal tumor seeding. Intraepithelial spreading occurs through continuous migration and cell proliferation which distributed to the whole urothelium. Second theory, the "field cancerization" effect; the carcinogen exposure causes the simultaneous genetic alteration on various primary urothelial layer. It resulted in the new multiple tumors which have no genetic correlation. ${ }^{9,23}$

\section{Conclusion}

Non-invasive urothelial carcinoma patients with multiple tumor characteristic which has low FGFR3 immunoexpression (histoscore $<6$ ) are more likely to suffer from recurrence compared to patients with high FGFR3 immunoexpression. Tumor multiplicity is an essential predictive factor in recurrences on non-invasive bladder urothelial carcinoma.

\section{Conflict of Interest}

All the authors state that they have no conflict of interest in this article.

\section{References}

1. Bosman FT, Jaffe ES, Lakhani SR, Ohgaki $\mathrm{H}$. Tumours of the urinary tract. In: Moch H, Humphrey PA, Ulbright TM, Reuter VE, editors. WHO classification of tumours of the urinary system and male genital organs. $4^{\text {th }}$ Edition. Volume 8. Lyon, France: International Agency for Research on Cancer (IARC) Press; 2016. p. 77-106.

2. Anastasiadis A, de Reijke TM. Best practice in the treatment of nonmuscle invasive bladder cancer. Ther Adv Urol. 2012;4(1):13-32.

3. Lombard AP, Mudryj M. The emerging role of the androgen receptor in bladder cancer. Endocr Relat Cancer. 2015;22(5):R265-77.

4. GLOBOCAN. Estimated cancer insidence, mortality and prevalence worldwide in 2012. Lyon, France: International Agency for Research on Cancer (IARC); 2012 [cited 2017 October 20]. Available from: http:// globocan.iarc.fr.

5. Jacobs BL, Lee CT, Montie JE. Bladder cancer in 2010: how far have we come? CA Cancer $\mathrm{J}$ Clin. 2010;60(4):244-72.

6. Li Y, Izumi K, Miyamoto H. The role of the androgen receptor in the development and progression of bladder cancer. Jpn J Clin Oncol. 2012;42(7):569-77.

7. Godoy G, Gakis G, Smith CL, Fahmy O. Effects of androgen and estrogen receptor signaling pathways on bladder cancer: initiation and progression. Bladder Cancer. 2016;2(2):12737.

8. di Martino E, Tomlinson DC, Knowles MA. A decade of FGF receptor research in bladder cancer: past, present, and future challenges. Adv Urol. 2012;2012:429213.

9. Cheng L, Lopez-Beltran A, Bostwick DG. Bladder pathology. $1^{\text {st }}$ Edition. Hoboken, New Jersey: John Wiley \& Sons; 2012.

10. Tiu A, Jenkins LC, Soloway MS. Active surveillance for low-risk bladder cancer. Urol Oncol. 2014;32(1):33.e7-10.

11. Pal SK, He M, Jones JO. Discovery of resistance pathways to fibroblast growth factor receptor inhibition in bladder cancer. Cancer Stud Ther J. 2017;2(6):231.

12. Nam JK, Park SW, Lee SD, Chung MK. Prognostic value of sex-hormone receptor expression in non-muscle-invasive bladder cancer. Yonsei Med J. 2014;55(5):1214-21.

13. Babjuk M, Burger M, Compérat E, Gontero P, Mostafid AH, Palou J, et al. EAU guidelines on non-muscle-invasive bladder cancer (TaT1 and CIS) [Internet]. European Association of Urology (EAU). 2017 [cited 2017 October 20]. Available from: https://uroweb.org/wpcontent/uploads/EAU-Guidelines-on-Nonmuscle-Invasive-BC_TaT1-2017.pdf.

14. Cheng L, Lopez-Beltran A, MacLennan GT, Montironi R, Bostwick DG. Neoplasms of the urinary bladder. In: Cheng L, Bostwick DG, editors. Urologic surgical pathology. $3^{\text {rd }}$ Edition. Philadelphia: Saunders; 2014. p. 243-76.

15. Li P, Chen J, Miyamoto H. Androgen receptor signaling in bladder cancer. Cancers (Basel). 2017;9(2):E20.

16. Cheng L, Davison DD, Adams J, LopezBeltran A, Wang L, Montironi R, et al. Biomarkers in bladder cancer: translational and clinical implications. Crit Rev Oncol Hematol. 2014;89(1):73-111.

17. Mashhadi R, Poumand G, Kosari F, Mehrsa A, Salem S, Pourmand MR, et al. Role of 
steroid hormone receptors in formation and progression of bladder carcinoma: a casecontrol study. Urol J. 2014;11(6):1968-73.

18. van Rhijn BW, Lurkin I, Radvanyi F, Kirkels WJ, van der Kwast TH, Zwarthoff EC. The fibroblast growth factor receptor 3 (FGFR3) mutation is a strong indicator of superficial bladder cancer with low recurrence rate. Cancer Res. 2001;61(4):1265-8.

19. Miyamoto H, Yao JL, Chaux A, Zheng Y, Hsu I, Izumi $\mathrm{K}$, et al. Expression of androgen and oestrogen receptors and its prognostic significance in urothelial neoplasm of the urinary bladder. BJU Int. 2012;109(11):171626.

20. Rosai J. Rosai and Ackerman's surgical pathology. $10^{\text {th }}$ Edition. New York: Mosby; 2018.

21. Bryan RT, Collins SI, Daykin MC, Zeegers MP, Cheng KK, Wallace DM, et al. Mechanisms of recurrence of $\mathrm{Ta} / \mathrm{T} 1$ bladder cancer. Ann $\mathrm{R}$
Coll Surg Engl. 2010;92(6):519-24

22. Cheng L, Zhang S, MacLennan GT, Williamson SR, Lopez-Beltran A, Montironi R. Bladder cancer: translating molecular genetic insights into clinical practice. Hum Pathol. 2011;42(4):455-81.

23. Yousef PG, Gabril MY. An update on the molecular pathology of urinary bladder tumors. Pathol Res Pract. 2018;214(1):1-6.

24. Mir C, Shariat SF, van der Kwast TH, Ashfaq R, Lotan Y, Evans A, et al. Loss of androgen receptor expression is not associated with pathological stage, grade, gender or outcome in bladder cancer: a large multi-institutional study. BJU Int. 2011;108(1):24-30.

25. Wei Hsu J, Hsu I, Xu D, Miyamoto H, Liang L, Ru Wu X, Shyr CR, Chang C. Decreased tumorigenesis and mortality from bladder cancer in mice lacking urothelial androgen receptor. Am J Pathol. 2013;182(5):1811-20. 